\title{
STUDI KOMPARATIF MODEL ASUHAN KEPERAWATAN PROFESIONAL (MAKP) TIM DAN FUNGSIONAL DENGAN TINGKAT KEPUASAN PASIEN DI RUMAH SAKIT UMUM DABO KECAMATAN SINGKEP KABUPATEN LINGGA TAHUN 2019
}

\author{
(Comparative Study Of Professional Nursing (MAKP) Care Team And Functional Care \\ With Patient Satisfaction Level In General Hospital Dabo Kecamatan Singkep Lingga \\ District, 2019)
}

\author{
Rizki Sari Utami - Herman- \\ *) Dosen Program Studi Ilmu Keperawatan STIKEes Awal Bros Batam \\ **)Mahasiswa Program Studi Ilmu Keperawatan STIKes Awal Bros Batam
}

\begin{abstract}
Age is one of the determinants of the length of sleep that the body needs. This problem often occurs in the elderly, so it has an impact on the quality of sleep. The Lingga Regency PPKB Health Office reports that 20-60\% of elderly people experience poor sleep quality. This study aims to determine and observe whether there is an effect of warm water bathing on the quality of old age sleep in Posyandu in Singkep District, Lingga Regency. This study used a quasi experiment method with a pre-test and post-test without control design. The sample used was total sampling with the number of respondents as many as 30 people. Analysis of research data using the Wilcoxon Test which had previously been tested in the Normality of Shapiro Wilk. The intervention used is foot soak (warm water). The results showed a significant change, in which the p-value was 0,000<0,05 with an average increase in sleep quality before foot soaking 10.00 and after intervention 1.60. So that it can be concluded that there is the effect of foot soak (warm water) on the quality of old sleep. It is hoped that the elderly will apply this relaxation technique to maintain their sleep quality.
\end{abstract}

Keywords : MAKP Team, Functional, Patient Satisfaction

\section{PENDAHULUAN}

Pelayanan keperawatan merupakan bagian integral dari pelayanan kesehatan di rumah sakit yang mempunyai peranan besar terhadap pencapaian efisiensi, mutu dan citra rumah sakit di mata masyarakat. Pelayanan keperawatan itu sendiri adalah suatu bentuk pelayanan kesehatan yang bersifat profesional dalam memenuhi kebutuhan dasar manusia meliputi bio-psiko-sosiokultural dan spiritual yang dapat ditunjuk pada individu dan masyarakat dalam rentang sehat, sakit (Martini, 2017). Pelayanan keperawatan diberikan karena adanya kelemahan fisik dan mental, keterbatasan pengetahuan serta kurangnya pengertian pasien akan kemampuan melaksanakan kegiatan secara mandiri. Kegiatan itu dilakukan dalam usaha mencapai peningkatan kesehatan dengan penekanan pada upaya pelayanan kesehatan yang memungkinkan setiap individu mencapai kemampuan hidup sehat dan produktif (Aditama, 2015).

Berdasarkan Undang-Undang No. 44 Tahun 2009 tentang Rumah sakit adalah institusi pelayanan kesehatan yang menyelenggarakan pelayanan kesehatan bagi perorangan secara menyeluruh dan paripurna dengan menyediakan pelayanan rawat inap, rawat jalan, dan gawat darurat (World Health Organization (WHO)) dalam Laksito, 2014). Pada hakekatnya rumah sakit berfungsi sebagai tempat penyembuhan penyakit dan pemulihan kesehatan dan fungsi 
dimaksud memiliki makna tanggung jawab yang seluruhnya merupakan tanggung jawab pemerintah dalam meningkatkan taraf kesejahteraan masyarakat. Peranan tenaga keperawatan dalam pelayanan kesehatan sangat besar khususnya di institusi pelayanan kesehatan rumah sakit. Perawat merupakan salah satu tenaga profesional yang jumlahnya terbanyak di rumah sakit, sehingga perlu upaya peningkatan mutu pelayanan rumah sakit melalui upaya peningkatan pelayanan keperawatan. Hal ini sejalan dengan pernyataan Putra S yang menyatakan bahwa tantangan pelayanan kesehatan di Indonesia adalah bagaimana memenuhi kebutuhan dan kepuasan pasien ( Ester Nunuk, 2017 ).

Kualitas pelayanan keperawatan di rumah sakit tidak akan berjalan dengan baik apabila proses keperawatan yang dilaksanakan tidak terstruktur dengan baik. Pelaksanaan keperawatan yang dilaksanakan sesuai dengan pelaksanaan asuhan keperawatan yang telah dibuat, maka kemungkinan untuk mencapai kepuasan pada pasien dapat terwujud. Dengan demikian jelaslah bahwa pemberian asuhan keperawatan merupakan motede penting dalam pelayanan di rumah sakit. Masalah yang dihadapi saat ini adalah belum terbentuknya layanan keperawatan professional sehingga layanan yang diberikan belum sesuai dengan tuntutan standar profesi (Utama, 2014). Untuk mengatasi masalah tersebut diperlukan sistem pemberian asuhan keperawatan, salah satunya melalui pengembangan Metode Asuhan Keperawatan Profesional. Metode pemberian asuhan keperawatan perlu disesuaikan dengan kondisi dan kebutuhan pasien. Metode pemberian asuhan keperawatan mempunyai keuntungan dan kerugiannya masing-masing.

Salah satu upaya untuk meningkatkan pelayanan keperawatan yang bermutu dan profesional adalah dengan menerapkan Model Asuhan Keperawatan Profesional
(MAKP), yang memungkinkan perawat profesional dalam mengatur pemberian asuhan keperawatan termasuk lingkungan untuk menopang pemberian asuhan tersebut. Pengembangan model asuhan keperawatan profesional dikembangkan untuk menjawab tantangan terhadap kualitas pelayanan dan asuhan keperawatan yang dirasakan belum memuaskan. Model asuhan keperawatan tim telah dilaksanakan di berbagai negara termasuk rumah sakit di Indonesia (Kasim dan Abdurrouf, 2016).

Salah satu strategi untuk mengoptimalkan peran dan fungsi perawat dalam pelayanan keperawatan adalah pembenahan dalam manajemen keperawatan dengan harapan adanya faktor kelola yang optimal, sehingga mampu menjadi wahana peningkatan keefektifan pembagian pelayanan keperawatan sekaligus lebih menjamin kepuasan pasien terhadap pelayanan keperawatan (Nursalam, 2015). Kepuasan dan loyalitas yang dirasakan dan diberikan oleh masyarakat adalah ukuran yang harus dicapai setiap masyarakat pada umumnya. Berdasarkan studi pendahuluan yang telah dilakukan peneliti pada Bulan Januari, didapatkan hasil bahwa di RSUD Dabo dari 7 ruangan rawat inap, 3 ruangan yang sudah menggunakan MAKP Tim dan 4 lainnya menggunakan MAKP Fungsional. Walaupun tidak semua ruangan inap menggunakan konsep manajemen tersebut, hal ini dilakukan Rumah Sakit karena untuk mengetahui seberapa maksimalnya penggunaan MAKP tersebut di ruangan. Selain itu tingkat pendidikan tenaga keperawatan di ruangan inap juga masih ada yang belum memenuhi kriteria apabila ditetapkan penggunaan MAKP Tim oleh karena itu beberapa ruangan yang lainnya masih menggunakan model asuhan keperawatan fungsional.

Kepuasan pasien banyak dipengaruhi secara langsung oleh mutu pelayanan yang 
diberikan rumah sakit terutama yang berhubungan dengan kompetensi perawat, waktu pelayanan, perilaku perawat pelaksana serta biaya/ tarif. RSUD Dabo Kecamatan Singkep merupakan salah satu Rumah Sakit yang dimiliki Pemerintahan Kabupaten Lingga yang memberikan pelayanan terhadap masyarakat luas dengan berbagai karakteristiknya, baik peserta Badan Penyelenggara Jaminan Sosial (BPJS) ataupun jaminan kesehatan nasional (JKN). Rumah Sakit Umum Daerah Dabo memiliki beberapa ruang perawatan meliputi ruang perawatan anak dan persalinan dengan jumlah perawat sebanyak 6 orang, ruang penyakit dalam ( zal laki dan zal wanita ) dengan jumlah perawat 10 orang perawat di zal laki dan 9 orang perawat di zal wanita, ruang perawatan $\mathrm{HCU}$ dengan 8 orang perawat, dan ruang perawatan VIP sebanyak 10 orang perawat. Namun dari beberapa ruang rawat inap yang ada di RSUD Dabo, penerapan Sistem Model Asuhan Keperawatan Tim hanya diberlakukan pada ruang perawatan penyakit dalam dan ruang perawatan VIP saja, dengan tingkat pendidikan yaitu SPK, D3 Keperawatan, Sarjana Keperawatan, dan Ners (Profil RSUD Dabo, 2019). Hasil wawancara dengan 10 orang pasien di ruang rawat inap yang ada di RSUD Dabo pada Bulan Januari 2020, diperoleh data bahwa 8 dari 10 orang pasien mengeluh tentang perawat yang kurang profesional dalam memberikan pelayanan kesehatan diantaranya mengatakan bahwa masih ada perawat yang tidak ramah dan acuh terhadap keluhan pasiennya, perawat juga tidak memperkenalkan diri kepada pasien maupun keluarga pasien, kurangnya penjelasan atau informasi dan komunikasi pada waktu memberikan asuhan keperawatan dan masih kurangnya monitoring dan observasi .

Penelitian tentang penerapan MAKP teah dilakukan oleh beberapa peneliti, salah satunya adalah Tukimin pada tahun 2015 untuk mengetahui gambaran tingkat kepuasan pasien pada kelompok yang mendapat implementasi MAKP tim, mengetahui gambaran tingkat kepuasan pasien pada kelompok yang tidak mendapat implementasi MAKP fungsional dan mengetahui perbedaan tingkat kepuasan pasien pada kelompok tim dan kelompok fungsional. Berdasarkan hasil penelitian dapat disimpulkan bahwa kelompok tim yang mendapatkan implementasi MAKP memiliki tingkat kepuasan yang lebih baik daripada kelompok fungsional yang tidak mendapatkan implementasi MAKP .

Berdasarkan uraian di atas maka peneliti tertarik untuk melakukan penelitian lebih lanjut mengenai sistem MAKP yang diterapkan di instansi Rumah Sakit. Sistem MAKP banyak macamnya, akan tetapi disini peneliti mengambil salah satu bentuk sistem MAKP yaitu MAKP Tim dan fungsional. Sehingga peneliti akan meneliti tentang apakah ada perbedaan penggunaan Model Asuhan Keperawatan Profesional (MAKP) Tim dan Fungsional demgan tingkat kepuasan pasien di RSUD Dabo Kecamatan Singkep Kabupaten Lingga Tahun 2019 .

\section{METODE}

Rancangan penelitian yang digunakan dalam penulisan ini adalah penelitian observasional dengan menggunakan desain non-experiment studi korelasi, dengan desain deskriptif dan pendekatan melalui penelitian cross sectional yang dapat diketahui pada waktu pengukuran observasi data variabel independen dan dependen hanya satu kali, pada satu saat. Penelitian ini dilakukan selama 7 hari dan pengisian kuisioner ini dibantu oleh beberapa tenaga kesehatan yang sedang dinas pada saat itu, tentunya tidak semua subjek penelitian harus diobservasi pada hari atau pada waktu yang sama, akan 
tetapi baik variabel independen maupun dependen dinilai hanya satu kali saja.

Penelitian ini dilakukan pada ruang rawat inap yang ada di RSUD Dabo Kabupaten Lingga, dengan teknik pengambilan sampel penelitian yaitu simple random sampling. Total populasi yang digunakan sebanyak 60 responden yang mana 30 responden merupakan pasien yang dirawat di ruang rawat inap dengan penerapan model asuhan keperawatan profesional (MAKP) tim dan 30 responden di ruang rawat inap dengan model asuhan keperawatan fungsional RSUD Dabo.

HASIL

Tabel 4.1

Distribusi Frekuensi Karakteristik Usia dan Jenis Kelamin dan Tingkat Pendidikan Responden

\begin{tabular}{|c|c|c|c|}
\hline $\begin{array}{l}\mathbf{N} \\
\mathbf{O}\end{array}$ & $\begin{array}{c}\text { KARAKTERISTIK } \\
\text { RESPONDEN }\end{array}$ & $\mathbf{f}$ & $\%$ \\
\hline \multirow[t]{4}{*}{1} & Usia & & \\
\hline & MAKP Tim & & \\
\hline & $\begin{array}{l}\text { - Usia (14-66 } \\
\text { Tahun) }\end{array}$ & 30 & 100 \\
\hline & $\begin{array}{l}\text { Fungsional } \\
-\quad \text { Usia }(20-68 \\
\quad \text { Tahun })\end{array}$ & 30 & 100 \\
\hline
\end{tabular}

2 Jenis Kelamin MAKP Tim

$\begin{array}{lll}\text { a. Laki-Laki } & 19 & 63,3 \\ \text { b. Perempuan } & 11 & 36,7 \\ \text { Total } & \mathbf{3 0} & \mathbf{1 0 0}\end{array}$

\section{Fungsional}

$\begin{array}{lll}\text { a. Laki-Laki } & 18 & 60,0 \\ \text { b. Perempuan } & 12 & 40,0 \\ \text { Total } & \mathbf{3 0} & \mathbf{1 0 0}\end{array}$

3. Pendidikan

\section{MAKP Tim}

a. SD

$13 \quad 43,3$

\begin{tabular}{lcc}
\hline b. SMP & 3 & 10,0 \\
c. SMA & 8 & 26,7 \\
d. D III & 4 & 13,3 \\
e. S1 & 2 & 6,7 \\
Total & $\mathbf{3 0}$ & $\mathbf{1 0 0}$ \\
& & \\
Fungsional & & \\
a. SD & 9 & 30,0 \\
b. SMP & 5 & 16,7 \\
c. SMA & 7 & 23,3 \\
d. D III & 6 & 20,0 \\
e. S1 & 3 & 10,0 \\
Total & $\mathbf{3 0}$ & $\mathbf{1 0 0}$ \\
& & \\
\hline
\end{tabular}

Berdasarkan tabel 4.1 di atas dapat dilihat bahwa jumlah keseluruhan responden sebanyak 60 orang, yaitu 30 responden yang merupakan pasien yang berada di rawat inap yang menggunakan MAKP Tim dan 30 orang responden yang dirawat di ruang rawat inap yang menggunakan Model Fungsional. Adapun karakteristik untuk usia responden, diketahui pada ruang rawat inap MAKP Tim berkisar usia 14 - 66 tahun, sedangkan rentang usia responden di ruang rawat inap model fungsional berkisar $20-68$ tahun. Untuk karakteristik jenis kelamin responden yang terbanyak pada MAKP Tim adalah Laki-Laki dengan total responden sebanyak 19 orang $(63,3 \%)$ dan perempuan 11 orang $(36,7 \%)$. Sedangkan pada ruang rawat inap yang menggunakan model Fungsional, karakteristik jenis kelamin yang banyak peneliti jumpai adalah perempuan sebanyak 18 orang dengan jumlah persentasi sebesar $60,0 \%$ dan jumlah responden laki-laki sebanyak 12 orang dengan hasil persentasi sebanyak 40,0 \%. Pendidikan dalam penelitian ini juga berpengaruh pada terhadap hasil observasi, yang mana pada penelitian ini peneliti jumpai, pasien yang dirawat di ruang rawat inap dengan MAKP Tim, mayoritas responden memiliki tingkat pendidikan SD sebanyak 13 orang $(43,3 \%)$, SMP sebanyak 3 orang $(10,0)$, SMA 
sebanyak 8 orang $(26,7 \%)$, D III sebanyak 4 orang $(13,3 \%)$ dan S1 sebanyak 2 orang dengan persentasi sebesar $6,7 \%$. Sedangkan pasien yang peneliti jumpai di ruang rawat inap dengan model fungsional memiliki tingkat pendidikan yang berbeda juga, untuk pendidikan SD sebanyak 9 orang (30,0\%), SMP sebanyak 5 orang $(16,7 \%)$, SMA sebanyak 7 orang $(23,3 \%)$, D III sebanyak 6 orang $(20,0 \%)$ dan pendidikan S1 sebanyak 3 orang $(10,0 \%)$.

Tabel 4.2

Distribusi Frekuensi Unsur-Unsur Pelayanan Berdasarkan Survey Kepuasan Masyarakat di Ruang Rawat Inap MAKP Tim

\begin{tabular}{cccc}
\hline $\begin{array}{c}\text { Unsur } \\
\text { Pelayanan }\end{array}$ & $r$ & mean & sd \\
\hline MAKP TIM & & &
\end{tabular}

\begin{tabular}{|c|c|c|c|}
\hline Persyaratan & 30 & 3,27 & 0,785 \\
\hline Prosedur & 30 & 3,40 & 0,742 \\
\hline $\begin{array}{l}\text { Waktu } \\
\text { Pelayanan }\end{array}$ & 30 & 2,30 & 0,952 \\
\hline Biaya/ Tarif & 30 & 3,10 & 0,662 \\
\hline $\begin{array}{l}\text { Produk } \\
\text { Layanan }\end{array}$ & 30 & 2,83 & 0,834 \\
\hline $\begin{array}{l}\text { Kompetensi } \\
\text { Pelaksana }\end{array}$ & 30 & 3,60 & 0,621 \\
\hline $\begin{array}{l}\text { Perilaku } \\
\text { Pelaksana }\end{array}$ & 30 & 3,73 & 0,450 \\
\hline $\begin{array}{l}\text { Penanganan } \\
\text { Pengaduan, } \\
\text { Saran dan } \\
\text { Masukan }\end{array}$ & 30 & 2,93 & 0,740 \\
\hline $\begin{array}{l}\text { Sarana dan } \\
\text { Prasarana }\end{array}$ & 30 & 3,43 & 0,626 \\
\hline Total & 30 & 30 & 30 \\
\hline
\end{tabular}

Berdasarkan tabel 4.2 diatas, dapat dilihat perbedaan tingkat kepuasan pasien di setiap unsur pelayanan yang didapat dari jawaban responden dengan menggunkan kuisioner survey kepuasan masyarakat. Untuk Unsur pelayanan pada persyaratan didapati nilai rata-ratanya 3,27 dengan standar deviasi 0,78 . Unsur prosedur nilai rata-ratanya 3,40 dengan standar deviasi 0,742 . Unsur waktu pelayanan nilai rataratanya 2,30 dengan standar deviasi 0,952. Unsur ke empat yang mana mengenai biaya/ tarif pelayanan di rumah sakit memiliki ratarata 3,10 dengan standar deviasi 0,662. Unsur produk layanan nilai rata-ratanya 2,83 dengan standar deviasi 0,834. Unsur kompetensi pelaksana nilai rata-ratanya 3,60 dengan standar deviasi 0,621 . Unsur perilaku pelaksana memiliki rata-rata 3,73 dengan standar deviasi 0,450. Unsur penanganan pengaduan, saran dan masukan memiliki nilai rata-rata sebesar 2,93 dengan standar deviasi 0,740 dan untuk unsur yang ke sembilan mengenai sarana dan prasarana dapat dilihat nilai rata-ratanya sebesar 3,43 dengan standar deviasi sebesar 0,626. Adapun masalah utama pada unsur pelayanan di ruangan yang menggunakan model asuhan keperawatan profesional (MAKP) tim adalah pada waktu pelayanan yang diberikan ke pasien dan tingkat kepuasan tertinggi pasien yaitu pada unsur perilaku dan kompetensi pelaksana.

Tabel 4.3

Distribusi Frekuensi Unsur-Unsur Pelayanan Berdasarkan Survey Kepuasan Masyarakat di Ruang Rawat Inap Fungsional

\begin{tabular}{llll}
\hline $\begin{array}{l}\text { Unsur } \\
\text { Pelayanan }\end{array}$ & $r$ & mean & sd \\
\hline FUNGSIONAL & &
\end{tabular}

$\begin{array}{llll}\text { Prosedur } & 30 & 2,97 & 0,809\end{array}$




\begin{tabular}{|c|c|c|c|c|}
\hline $\begin{array}{l}\text { Waktu } \\
\text { Pelayanan }\end{array}$ & 30 & 3,17 & 0,834 & \multirow{6}{*}{$\begin{array}{l}\text { prasarana nilai rata-ratanya sebesar } 3,13 \\
\text { dengan standar deviasi } 0,730 . \text { Adapun } \\
\text { masalah utama dari tingkat kepuasan pasien } \\
\text { berdasarkan unsur pelayanan yang diberikan } \\
\text { di ruangan yang menggunakan model asuhan } \\
\text { keperawatan fungsional adalah masalah pada } \\
\text { unsur pelayanan biaya/ tarif, sedangkan nilai } \\
\text { rata-rata tertinggi dari tingkat kepuasan } \\
\text { pasien pada model asuhan keperawatan } \\
\text { fungsional adalah perilaku pelaksana dan } \\
\text { waktu pelayanan yang diberikan. Pasien } \\
\text { merasakan tingkat kepuasan yang lebih tinggi } \\
\text { pada sikap dan waktu pelayanan yang } \\
\text { diberikan oleh perawat pada ruangan yang } \\
\text { menggunakan model asuhan keperawatan } \\
\text { fungsional. }\end{array}$} \\
\hline Biaya/ Tarif & 30 & 2,10 & 0,803 & \\
\hline $\begin{array}{l}\text { Produk } \\
\text { Layanan }\end{array}$ & 30 & 2,83 & 0,950 & \\
\hline $\begin{array}{l}\text { Kompetensi } \\
\text { Pelaksana }\end{array}$ & 30 & 2,37 & 0,615 & \\
\hline $\begin{array}{l}\text { Perilaku } \\
\text { Pelaksana }\end{array}$ & 30 & 3,17 & 0,874 & \\
\hline $\begin{array}{l}\text { Penanganan } \\
\text { Pengaduan, } \\
\text { Saran dan } \\
\text { Masukan }\end{array}$ & 30 & 2,57 & 0,728 & \\
\hline $\begin{array}{l}\text { Sarana dan } \\
\text { Prasarana }\end{array}$ & 30 & 3,13 & 0,730 & \multirow{2}{*}{$\begin{array}{c}\text { Tabel } 4.4 \\
\text { Perbedaan Tingkat Kepuasan Pasien di } \\
\text { Ruangan yang Menggunakan MAKP Tim } \\
\text { dan Ruangan dengan Model Fungsional } \\
\text { - Berdasarkan Unsur Pelayanan dari Hasi } \\
\text { Survey Kepuasan Masyarakat (SKM) }\end{array}$} \\
\hline \multirow{4}{*}{\multicolumn{4}{|c|}{$\begin{array}{l}\text { Dari hasil tabel } 4.3 \text { diatas dapat dilihat } \\
\text { model asuhan keperawatan fungsional juga } \\
\text { memiliki tingkat kepuasan yang berbeda- } \\
\text { beda di setiap unsur pelayanannya. Yang } \\
\text { mana pada unsur pertama yaitu pada unsur } \\
\text { persyaratan didapati nilai rat-ratanya sebesar } \\
\text { 3,10 dengan standar deviasi } 0,803 \text {. Unsur }\end{array}$}} & \\
\hline & & & & Variabel \\
\hline & & & & $\begin{array}{l}\text { MAKP } \\
\text { Tim }\end{array}$ \\
\hline & & & & Fungsional \\
\hline
\end{tabular}
prosedur nilai rata-ratanya 2,97 dengan standar deviasi 0,890. Unsur waktu pelayanan nilai rata-ratanya 3.17 dengan standar deviasi 0,834 . Untuk unsur biaya/ tarif didapati nilai rata-ratanya sebesar 2,10 dengan standar deviasi 0,803 . Unsur produk layanan nilai rata-ratanya 2,83 dengan standar deviasi 0,950. Unsur kompetensi pelaksana nilai rata-ratanya sebesar 2,37 dengan standar deviasi 0,615. Unsur perilaku pelaksana nilai rata-ratanya sebesar 3,17 dengan standar deviasi 0,874. Unsur penanganan pengaduan, saran dan masukan didapati nilai rata-ratanya sebesar 2,57 dengan standar deviasi 0,728 dan pada unsur yang ke sembilan yaitu unsur sarana dan

Berdasarkan hasil rata-rata dari tabel 4.4 diatas, dapat dilihat adanya perbedaan yang signifikan antara penerapan model asuhan keperawatan profesional (MAKP) tim dengan model fungsional, yang mana skor rata-rata pada MAKP Tim sebesar 3,178 dengan $p$-value 0,000 , sedangkan pada model fungsional dapat dilihat skor rata-ratanya sebesar 2,822 dan p-value sebesar 0,000. Sehingga dapat disimpulkan berdasarkan kesimpulan dari Uji Sampel T-Test adalah jika ( $p$-Value < 0,05) maka H0 ditolak dan Ha diterima yang artinya dapat disimpulkan pada penelitian ini adanya perbedaan yang signifikan antara pemberian model asuhan 
keperawatan profesional (MAKP) tim dengan model asuhan keperawatan fungsional.

\section{PEMBAHASAN}

Profesi keperawatan harus selalu berfokus pada klien/pasien (client oriented), mengedepankan sifat mementingkan klien dan merasa lebih bertanggung jawab dalam pelayanan keperawatan. Bukan hanya perjuangan untuk mempertahankan eksistensi, hak-hak dan kepentingan kelompok perawat (Wuryanto, 2016). Oleh karna itu pentingnya pemberian asuhan keperawatan yang tepat dalam memberikan pelayanan bagi klien. Dalam pemberian asuhan keperawatan, ada beberapa metode yang digunakan, disini peneliti hanya meneliti dua jenis model asuhan keperawatan, yaitu model asuhan keperawatan profesional (MAKP) Tim dan Model Fungsional terhadap tingkat kepuasan pasien.

Berdasarkan tabel 4.4, dapat dilihat adanya perbedaan yang signifikan antara 30 reponden yang dirawat di ruang rawat inap dengan penerapan model asuhan keperawatan profesional (MAKP) tim dengan 30 responden yang dirawat di ruang rawat inap yang menerapkan model fungsional, yang mana skor rata-rata dari tingkat kepuasan pasien pada MAKP Tim sebesar 3,178 dengan p-value 0,000, sedangkan tingkat kepuasan pasien pada model fungsional dapat dilihat skor rataratanya sebesar 2,822 dan p-value sebesar 0,000. Pada penelitian ini peneliti melakukan uji sampel T-test yang mana dapat disimpulkan pada penelitian ini adanya perbedaan yang signifikan, antara MAKP tim dan model fungsional yang mana ( $p$-Value < $0,05)$ sehingga $\mathrm{H} 0$ ditolak dan $\mathrm{Ha}$ diterima yang artinya hal ini menunjukkan adanya perbedaan yang signifikan antara tingkat kepuasan pasien dengan model asuhan keperawatan profesional (MAKP) tim dengan tingkat kepuasan pasien pada model asuhan keperawatan fungsional. Sesuai dengan pernyataan Nursalam (2015) Keberhasilan suatu asuhan keperawatan kepada pasien sangat ditentukan oleh pemilihan model pemberian asuhan keperawatan profesional. Dengan semakin meningkatnya kebutuhan masyarakat akan pelayanan keperawatan dan tuntutan perkembangan iptek, maka model sistem pemberian asuhan keperawatan harus efektif dan efisien .

Asuhan keperawatan adalah faktor penting dalam survival pasien dan dalam aspek - aspek pemeliharaan, rehabilitatif dan preventif perawatan kesehatan. Untuk sampai pada hal ini, proses keperawatan telah mengidentifikasi proses pemecahan masalah yang menggabungkan elemen yang paling diinginkan dari seni keperawatan dengan elemen yang paling relevan dari sistem teori, dengan menggunakan metode keperawatan menurut Shore (2014). Berdasarkan MAKP yang sudah dikembangkan di berbagai rumah sakit, Hoffart \& Woods (2016) menyimpulkan bahwa MAKP terdiri lima komponen yaitu nilai - nilai professional yang merupakan inti MAKP, hubungan antar professional, metode pemberian asuhan keperawatan, pendekatan manajemen terutama dalam perubahan pengambilan keputusan serta sistem kompensasi dan penghargaan. Sehingga dapat disimpulkan baiknya suatu pelayanan di rumah sakit tergantung pada pemilihan metode apa yang diterapkan dalam pemberian asuhan keperawatan yang professional .

\section{KESIMPULAN}

Berdasarkan hasil dari penelitian yang telah dilakukan melalui proses wawancara, pengkajian, pengisian kuisioner serta analisis data yang dilakukan terhadap 30 reponden yang dirawat di ruang rawat inap dengan 
MAKP Tim dan 30 reponden di ruang rawat inap dengan Model Fungsional, dapat disimpulkan bahwa adanya perbedaan yang signifikan terhadap tingkat kepuasan pasien dalam model asuhan keperawatan profesional (MAKP) Tim dengan Model Fungsional yang ada di RSUD Dabo, yang mana berikut ini adalah rincian kesimpulan dari hasil penelitian yang telah dilakukan:

1. Dari sembilan unsur pelayanan yang tercantum dalam survey kepuasan masyarakat (SKM), yang mana kuisioner ini bertujuan untuk menentukan tingkat kepuasaan pasien yang dirawat di ruang rawat inap dengan penerapan model asuhan keperawatan profesional (MAKP) tim di RSUD Dabo. Adapun hasil dari analisis data yang dilakukan, ditemukan masalah utama pada MAKP tim ini adalah pada waktu pemberian pelayanan asuhan keperawatan yang mana nilai skor rata-ratanya sebesar 2,30 dengan standar deviasi 0,952 sedangkan untuk tingkat kepuasan tertinggi pasien adalah pada unsur prilaku pelaksana dalam pemberian asuhan keperawatan dengan skor ratarata 3,73 dan standar deviasi 0,450. Sehingga dapat disimpulkan pada model ini perilaku pelaksana lebih tinggi karna pada model ini perawat dituntut untuk bertanggung jawab dalam pemberian asuhan keperawatan serta bekerjasama dengan anggota tim lainnya sehingga terwujudnya kepuasan pasien sesuai standar yang berlaku di RSUD Dabo.

2. Sedangkan tingkat kepuasan pasien yang di rawat di ruang rawat inap yang menerapkan model asuhan keperawatan fungsional, dari 30 responden yang dilakukan uji tingkat kepuasan melalui instrumen kepuasan pasein di dapati masalah utama dalam model fungsional ini adalah pada unsur biaya/ tarif dengan skor rata-ratanya sebesar 2,10 dan standar deviasi 0,803 dan tingkat kepuasan tertinggi pasien terletak pada perilaku pelaksana dengan skor rata-rata 3,17 dengan standar deviasi 0,874 karna pada model fungsional ini dilakukan penerapan manajemen klasik yang menekankan efisiensi, pembagian tugas yang jelas dan pengawasan yang baik sehingga terwujudnya perilaku pelaksana yang baik terhadap tingkat kepuasan pasien.

3. Dari hasil penelitian yang bersifat membandingkan tingkat kepuasan pasien terhadap dua model asuhan keperawatan yang ada di RSUD Dabo, dapat disimpulkan skor rata-rata tingkat kepuasan pasien pada MAKP Tim sebesar 3,178 dengan p-value 0,000 sedangkan skor rata-rata model fungsional sebesar 2,822 dengan $p$ value 0,000 . Sehingga dapat disimpulkan adanya perbedaan yang signifikan antara tingkat kepuasan pasien yang di rawat di ruang rawat inap dengan penerapan MAKP Tim dengan tingkat kepuasan pasien yang di rawat di ruang rawat inap dengan penerapan Model Fungsional. Adapun nilai kemaknaan berdasarkan Uji sampel T-test yang telah dilakuakan adalah jika ( $p$ value < 0,05) maka dapat disimpulkan bahwa $\mathrm{H}_{0}$ ditolak dan Ha diterima yang artinya hal ini menunjukkan adanya perbedaan yang signifikan antara skor rata-rata dari tingkat kepuasan dalam penerapan Model Asuhan Keperawatan Profesional (MAKP) Tim dengan tingkat kepuasan terhadap kinerja perawat dalam penerapan Model Asuhan Keperawatan Fungsional. 


\section{SARAN}

1. Bagi Institusi Pendidikan

Memberikan informasi tentang bagaimana bentuk penggunaan model asuhan keperawatan professional yang lebih efektif pada Rumah Sakit sehingga bisa menambah ilmu pengetahuan keperawatan khususnya pada mata pelajaran manajemen keperawatan. Sehingga dalam pembelajaran bisa dijadikan bahan referensi oleh pihak institusi Pendidikan .

\section{Bagi Rumah Sakit}

Memberikan gambaran tentang pengaruh pemberian model asuhan keperawatan profesional terhadap kepuasan klien rawat inap sehingga dapat dijadikan bahan evaluasi untuk mengembangkan layanan keperawatan yang dapat memuaskan pasien .

\section{Bagi Peneliti}

Sarana pembelajaran yang nyata tentang konsep pemberian asuhan keperawatan professional pada Rumah Sakit. Sehingga peneliti dapat mengetahui bagaimana manajemen keperawatan yang harus diterapkan dalam ruangan pada saat peneliti berada dalam lingkungan pekerjaan di ruang rawat inap Rumah Sakit .

\section{DAFTAR PUSTAKA}

B., Munif.,.(2017). HUBUNGAN PENERAPAN MPKP TIM DENGAN TINGKAT KEPUASAN PASIEN DI RUANG RAWAT INAP RSUD BLAMBANGAN BANYUWANGI Abi Mas Udianto 1), Badrul Munif 2) dan Citra Indra Gustian 3) 1), 5(2), 72-85. Djohan, B., \& Indonesia, U. (n.d.). Tingkat kepuasan pasien terhadap pelayanan perawat di unit gawat darurat rumah sakit haji jakarta.
Gowa, K. A. B. (2014). Pengaruh model asuhan keperawatan terhadap tingkat kepuasan pasien pengguna yankestis dalam pelayanan keperawatan di rsud syech yusuf kab.gowa, $\operatorname{VII}(2)$.

GUNARI, GUNARI (2015) HUBUNGAN PENERAPAN MODEL ASUHAN KEPERAWATAN PROFESIONAL (MAKP) TIM DENGAN KEPUASAN PASIEN DI RSUD JOMBANG. Other thesis, Universitas Pesantren Tinggi Darul Ulum.

Hafizurrachman, M. (2017). Kepuasan Pasien dan Kunjungan Rumah Sakit, (August). https://doi.org/10.21109/kesmas.v4i1.19 5

Hidayah, N., Ilmu, F., Universitas, K., Negeri, I., \& Makassar, A. (2014). Manajemen model asuhan keperawatan profesional (makp) tim dalam peningkatan kepuasan pasien di rumah sakit, $\operatorname{VII}(2)$.

K., Ngudi, R., \& Wlingi, W. (2014). FERLIN MEGA LIYANA STUDI KOMPARATIF PENGGUNAAN MODEL ASUHAN.

Kuntoro, W., \& Istiono, W. (2017). Kepuasan Pasien Terhadap Kualitas Pelayanan di Tempat Pendaftaran Pasien Rawat Jalan Puskesmas Kretek Bantul Yogyakarta, 2(1).

Kuntoro, W., \& Istiono, W. (2017).

Kepuasan Pasien Terhadap Kualitas Pelayanan di Tempat Pendaftaran Pasien Rawat Jalan Puskesmas Kretek Bantul Yogyakarta, 2(1).

Kustiyah, E. (2014). Analisis kepuasan pasien rawat inap atas pelayanan rumah sakit umum kabupaten sragen. 
Maimun, N., Studi, P., Medik, R., Stikes, K., \& Tuah, H. (2016). Mutu pelayanan di Rumah Sakit Bhayangkara Pekanbaru The Performance Of Nursing In Hospital Bhayangkara Pekanbaru, 3(5), 65-68.

Maslita,K. (2017). Gambaran kepuasan pasien di ruang rawat inap rumah sakit umum kabupaten tangerang.

Mizarra, Y. (2018). Hubungan Metode Penugasan Asuhan Keperawatan Tim di Instalasi Rawat Inap Rumah Sakit Daerah Kota Padangsidimpuan Tahun 2017.

Musi, K., \& Tahun, R. (2015). ANALISIS KOMPETENSI PERAWAT DALAM MEMBERIKAN PELAYANAN KESEHATAN DI RUMAH SAKIT dr. Sobirin

P., Irina, D. I., Prof, C. R., Manado, R. D. K., Hamel, R. S., Tim, P. M., \& Pelaksana, K. P. (2017). HUBUNGAN PENERAPAN METODE TIM, 5.

Rakhmawati, O. W., Kp, S., \& Kep, M. (2018). Metode penugasan tim dalam asuhan keperawatan, 1-9.

Reformasi, D. A. N., \& Republik, B. (2017).

Survei Kepuasan Masyarakat

Permenpan 14 Tahun 2017 Bagian

Organisasi Sekretariat Daerah. (n.d.).

Rudianti, Y., Handiyani, H., \& Sabri, L. (2016). PENINGKATAN MUTU PELAYANAN RUMAH SAKIT MELALUI Pendahuluan Metode Hasil, 16(1), 25-32.

Siahaan, D. N., \& Tarigan, M. (2006).

Kepuasan pasien terhadap asuhan keperawatan yang diberikan di rumah sakit tk ii putri hijau medan.
Utama, P. Y., Apriatni, E. P., \& Listyorini, S. (2013). RUMAH SAKIT ISLAM SULTAN AGUNG SEMARANG 1-9.

Widiasari. (2019). KEPUASAN PASIEN

TERHADAP PENERAPAN

KESELAMATAN PASIEN

Pendahuluan Hasil Metode, 22(January), 43-52. 